\title{
Zeolitin Farklı Tekstür Sınıfındaki Toprakların Fiziksel Özellikleri Üzerine Etkileri
}

\author{
Ekrem Lütfi AKSAKAL* (D) Yeliz BUDAK \\ Atatürk Üniversitesi, Ziraat Fakültesi, Toprak Bilimi ve Bitki Besleme Bölümü, Erzurum, Türkiye \\ (*Sorumlu yazar e-mail: elaksakal@atauni.edu.tr) \\ DOI: 10.17097/ataunizfd.480777
}

Geliş Tarihi (Received Date): 09.11.2018

Kabul Tarihi (Accepted Date): 14.05.2019

\begin{abstract}
ÖZ: Toprağın fiziksel özelliklerinin geliștirilmesi için pek çok organik ve inorganik toprak düzenleyici kullanılmasına rağmen zeolitin toprak fiziksel özellikleri üzerine etkilerini ortaya koyan araştırmalar çok sınırlıdır. Bu çalışma, kil (toprak I), tın (toprak II) ve kumlu tın (toprak III) tekstür sınıfındaki toprakların bazı fiziksel özellikleri üzerine zeolit (klinoptilolit) uygulamalarının etkilerini ortaya koymak amacıyla laboratuvar şartlarında yürütülmüştür. Zeolit uygulamaları ortalama ağırlıklı çap değerlerini toprak I'de 9.24 mm'den 5.06 mm'ye, toprak II'de 5.16 mm'den 4.14 mm'ye düşürürken, toprak III'de 2.61 mm'den 2.77 mm'ye yükseltmiștir. Zeolit uygulamaları araștırma topraklarının tüm agregat fraksiyonlarında agregat stabilitesi değerlerini önemli seviyede artırırken, dispersiyon oranını ise önemli seviyede düşürmüştür. Genel ortalama agregat stabilitesi değeri kontrolde $\% 26.64$ iken zeolit uygulama dozunun artışı ile artış göstermiş, $\% 5$ uygulama dozunda $\% 43.51$ olarak belirlenmiş ve kontrole göre \%63 oranında artıșın meydana geldiği belirlenmiștir. Zeolit uygulamaları topraklarının hacim ağırlıklarını önemli ölçüde düşürdüğü, porozite ve hidrolik iletkenlik değerlerini ise önemli ölçüde artırdığı belirlenmiştir. Genel ortalamada, kontrol seviyesinde hacim ağırlı̆̆ değeri $1.16 \mathrm{~g} \mathrm{~cm}^{-3}$ iken $\% 1,3$ ve 5 zeolit uygulamaları sonrasında $1.10,1.08$ ve $1.06 \mathrm{~g} \mathrm{~cm}^{-3}$ olarak ölçülmüştür. Genel ortalamada, kontrol seviyesinde hidrolik iletkenlik değeri $21.45 \mathrm{~cm} \mathrm{~h}^{-1}$ iken $\% 1,3$ ve 5 zeolit uygulamaları sonrasında $27.04,30.51$ ve $38.37 \mathrm{~cm} \mathrm{~h}^{-1}$ e yükseldiği belirlenmiştir. Sonuçlar, toprağın fiziksel özelliklerinin iyileștirilmesi amacıyla zeolitin toprak düzenleyici olarak kullanılabileceğini göstermektedir.
\end{abstract}

Anahtar kelimeler: Zeolit, Agregat büyüklük dağılımı, Agregat stabilitesi, Dispersiyon oranı, Hacim ağırlı̆̆ı, Hidrolik iletkenlik

\section{Effects of Zeolite on Physical Properties of Different Textured Soils}

\begin{abstract}
Despite the use of several organic and inorganic soil conditioners for development of the physical properties of the soil, the investigations on the effects of zeolite on soil physical properties are very scarce. This laboratory study was carried out to determine the effects of zeolite (clinoptilolite) with different rates on soil physical properties in soils with different textures [clay (soil I), loam (soil II), sandy loam (soil III)]. Mean weight diameter of soil I decreased from $9.24 \mathrm{~mm}$ to $5.06 \mathrm{~mm}$ with zeolite application. These values were obtained as $5.16 \mathrm{~mm}$ to $4.14 \mathrm{~mm}$ and $2.61 \mathrm{~mm}$ to $2.77 \mathrm{~mm}$ for soils II and III, respectively. Zeolite applications significantly increased aggregate stability of all the soils in all aggregate size fractions as compared to the controls. Dispersion ratio of soils amended with zeolite showed significant decreases. Whereas the aggregate stability of control was $26.64 \%$, it increased to $43.51 \%$ with $5 \%$ zeolite application, which is almost $63 \%$ greater than that of control. Zeolite applications on all three soils significantly decreased bulk density and increased porosity and hydraulic conductivity. When means were compared it is seen that the control bulk density value $\left(1.16 \mathrm{~g} \mathrm{~cm}^{-3}\right)$ decreased to $1.10,1.08$ and $1.06 \mathrm{~g} \mathrm{~cm}^{-3}$ with $1 \%, 3$ and 5 zeolite application, respectively. While the hydraulic conductivity was determined as $21.45 \mathrm{~cm} \mathrm{~h}^{-1}$ in control, it was determined as $27.4,30.51$ and $38.37 \mathrm{~cm} \mathrm{~h}^{-1}$ for $1 \%, 3$ and 5 zeolite application rates, respectively. Results have shown that zeolite can be used as an amelioration material to improve soil physical properties.
\end{abstract}

Keywords: Zeolite, Aggregate size distribution, Aggregate stability, Dispersion ratio, Bulk density, Hydraulic conductivity

\section{GİRIŞ}

Nüfus artışına paralel olarak ihtiyaçların artması kullanılabilir sınırlı tarım alanlarında uygulanan tarımsal faaliyetlerin yoğunluğunu ve tarım alanları üzerindeki baskıyı artırmıştır. Artan yoğun tarımsal uygulamalar toprakların fiziksel, kimyasal ve biyolojik dengesinin bozulmasına, verimlilik ve üretkenlik potansiyelinin tahrip olmasına neden olmuştur. Verimlilik ve üretkenlik parametreleri bakımından tahrip olmuş tarım topraklarının yerine alternatifinin bulunamamış olması, toprakların verimlilik ve üretkenliğinin bozulmasına yol açan süreç ve faktörlerin belirlenmesi, tahrip olmuş toprakların sslahı ve üretkenliğinin yeniden sağlanabilmesi için yapılması gereken sürdürülebilir tarımsal faaliyetlerin araştııılmasını zorunlu hale getirmiştir. Sürdürülebilir tarımsal faaliyetler ise ancak erozyonun önlenmesi, toprağın bozulan fiziksel, kimyasal ve biyolojik özelliklerinin iyileştirilmesi ve geliştirilmesi ile toprak kalitesinin artırılmas1, fonksiyonlarını optimal seviyede yerine getirebilmesi ve gelecekteki kullanımlar için iyi yönetilmesi ve bozulmasının önlenmesi ile mümkün olabilmektedir.

Toprak fiziksel özelliklerinin geliştirilmesi ve stabil agregatların oranını arttırarak erozyonun azaltılması, bitkilere daha uygun bir gelişme ortamı ve daha yüksek üretkenlik sağlamak amacıyla ahır gübresi ve kompost gibi organik atıkların toprağa ilave edilmesi en yaygın yöntem olarak uygulanmaktadır (Wallace and Terry, 1998; Hosseinpur et al., 2012). Ayrica, son yıllarda polivinilalkol ve poliakrilamid gibi yapay kimyasal 
kompleksler ile diatomit, vermikülit ve perlit gibi doğal katk1 maddeleri de geniş ölçüde deneme ve uygulamaya alınmıştır (Zhao and Xu, 1995; Sojka and Lentz, 1997). Ancak, toprak düzenleyicisi olarak doğal zeolitin toprak fiziksel özellikleri üzerine etkilerini ortaya koymak için yapılmış çalışmalar çok sınırlı düzeydedir.

Isıtıldıklarında yapılarında bulunan suyun çıkarken köpürmesinden dolayı Yunanca "kaynayan taş" anlamına gelen zeolit, ilk olarak 1756 yllında İsveç'li kimyager ve mineralog Axel Fredicka Cronstedt tarafindan bulunmuştur. Doğada 48 zeolit minerali türü tespit edilmesine rağmen 7 tür (klinoptilolit, mordenit, şabazit, erionit, ferrierit, flipsit ve analsit) bol miktarlarda ve yüksek saflıkta bulanmaktadır. Klinoptilolit tarımsal uygulamalarda toprak düzenleyici olarak en yaygın kullanılan zeolit türüdür (Wehtje et al., 2003; Wang and Peng 2010).

Zeolit, volkanik küllerin su ortamında değişime uğramasıyla oluşmuş doğal bir mineraldir. Zeolit mineralleri, alkali ve toprak alkali katyonların $\mathrm{Na}^{+}$, $\mathrm{K}^{+}, \mathrm{Ca}^{+2}$ ve $\mathrm{Mg}^{+2}$ gibi elementleri değişebilir formda içeren, birbirine oksijen atomlarını paylaşarak bağlanan tetrahedral $\left(\mathrm{SiO}_{4}\right)^{-4}$ ve $\left(\mathrm{AlO}_{4}\right)^{-5}$ 'in sinırsız uzayabilen üç boyutlu ağından oluşan sulu aluminosilikat yapısındadır. Yapıları bal peteği, kafese benzeyen, geniş iç ve dış yüzey alanlara sahip mikro gözenekli yapıdadır. Zeolitlerin genel formülü $\mathrm{x}\left[\left(\mathrm{M}^{+}, \mathrm{M}^{++}\right) \cdot\left(\mathrm{AlO}_{2}\right)\right] \cdot \mathrm{ySiO}_{2} \cdot \mathrm{zH}_{2} \mathrm{O}$ şeklinde olup, $\mathrm{M}^{+}$; $\mathrm{Na}^{+}, \mathrm{K}^{+}$gibi tek değerlikli katyonları ve $\mathrm{M}^{++}$ise $\mathrm{Ca}^{++}, \quad \mathrm{Mg}^{++}$gibi iki değerlikli katyonları simgelemektedir (Chon et al., 1996).

Zeolitler, yüksek iyon değişim kapasiteleri, gözenekli yapısı, moleküler elek olma özelliği, katalizör özelliği, düşük yoğunluğu ve dehidratasyon özelliğinden dolayı inşaat, yer bilimleri, fizik, kimya, ziraat, hayvancılık ve sağlık sektörü gibi çok çeşitli alanlarda kullanılabilmektedir (Chon et al., 1996; Wang and Peng, 2010).

Zeolitlerin iyon değişim kapasiteleri ile adsorpsiyon kapasitelerinin yüksek olması, iyon seçicilik özelliğinin olması, yarayışlı elementlerin hemen hepsini ve suyu bünyesinde depolayarak bitkilerin gerektiği zaman kullanmasına olanak veren özelliğinden dolayı toprak düzenleyicisi olarak kullanılmalarına olanak sağlamaktadır (Susana et al., 2015). Zeolit uygulamalarının toprakların katyon değişim kapasitelerini (DeSutter and Pierzynski, 2005), bitki besin elementi ve su tutma kapasitelerini (Dwyer and Dyer, 1984), yarayışlı N, P, Ca ve Mg miktarlarını (Abdi et al., 2006), kullanılan gübrelerin etkinliğini (Bansiwal et al., 2006), mikrobiyal aktivite ve mikrobiyal biyokütleyi artırarak (Chander and Joergensen, 2002), besin elementlerinin yıkanmasını ve topraktan kaybını azaltarak (Kithome et al., 1998) daha iyi bitki gelişimi sağladığı ve verimi arttırdığı bildirilmektedir. Zeolitin bitki besin elementlerinin topraktan yıkanmasını azalttığ ve besin elementlerinin etkinliğini $\operatorname{artırdığ~}$ çalışmaların özellikle bitkisel gelişim ile üretimi ve toprak verimliliği üzerine yoğunlaşmasina neden olmuştur (Allen et al., 1995; Leggo, 2000; Torma et al., 2014).

Toprak strüktürü bitki büyüme faktörü olmamasına rağmen, bitki büyümesi ile dolaylı olarak yakından ilgili olmasından dolayı sürdürülebilir tarım için korunması ve geliştirilmesi zorunludur. Strüktürel parametreler toprakların su ve hava geçirgenliklerini, su ve hava kapasitelerini, bitki besin elementlerinin yarayışlılı̆̆ını, mikroorganizma aktivitesini, kök nüfuzunu, toprağın işlenme kolaylığını önemli ölçüde etkilemektedir (Bronick and Lal, 2005). Toprak düzenleyicisi olarak doğal zeolitin toprak fiziksel özellikleri üzerine etkilerini belirlemek için yapılan çalışmaların çok sınırlı düzeyde olmasından dolayı; bu çalışmada, zeolitin farklı tekstüre sahip toprakların bazı fiziksel özellikleri üzerine etkilerini ortaya koymak amaçlanmıştır.

\section{MATERYAL VE METOT}

\section{Araştırma toprakları}

Araştırmada bazaltik, kireçtaşı ve kollufulivial ana materyal üzerinde oluşmuş Haplustert, Ustorthent ve Fluvaquent büyük toprak gruplarına ait topraklar kullanılmıştır. Toprak örnekleri benzer toprak nem ve sicaklik rejimine sahip, \%2-4 hafif eğimli tarım arazilerinin $0-20 \quad \mathrm{~cm}^{\prime} l i k$ işleme katmanından alınmıştır. Araştırma konusu topraklara ait tanımlayıcı bazı fiziksel ve kimyasal özellikler Çizelge 1'de verilmiştir.

\section{Zeolit (Klinoptilolit)}

Araştırmada tektosilikat yapısında tabakalı yapı gösteren zeolit (Klinoptilolit) kullanılmıştır. Kullanılan klinoptilolit \%95 saflıkta olup (\%5 oranında kristobalit ve tridimit içermekte) kimyasal formülü $\quad\left(\mathrm{Ca}, \mathrm{K}_{2}, \mathrm{Na}_{2}, \mathrm{Mg}\right)_{4} \mathrm{Al}_{8} \mathrm{Si}_{40} \mathrm{O}_{96} .24 \mathrm{H}_{2} \mathrm{O}$ 'dir. Klinoptilolitin bazı özellikleri Çizelge 1'de verilmiştir. 
Çizelge 1. Araştırma topraklarının ve zeolitin bazı tanımlayıcı özellikleri

\begin{tabular}{|c|c|c|c|c|}
\hline Parametreler & Toprak I & Toprak II & Toprak III & Zeolit \\
\hline Kil (\%) & $61.39 \pm 1.29$ & $25.68 \pm 1.20$ & $13.64 \pm 0.60$ & \\
\hline Silt (\%) & $21.31 \pm 0.03$ & $41.96 \pm 1.50$ & $24.93 \pm 1.14$ & \\
\hline Kum (\%) & $17.30 \pm 1.25$ & $32.36 \pm 1.28$ & $61.43 \pm 1.32$ & \\
\hline Tekstür sınıfı & Kil & Tin & Kumlu tın & \\
\hline Büyük toprak grubu & Haplustert & Fluvaquent & Ustorthent & \\
\hline Tarla kapasitesi (\%) & $44.12 \pm 1.21$ & $26.96 \pm 1.15$ & $19.12 \pm 0.93$ & \\
\hline $\left.\mathrm{KDK}(\mathrm{cmol} \mathrm{kg})^{-1}\right)$ & $52.94 \pm 1.30$ & $30.73 \pm 0.96$ & $19.25 \pm 0.71$ & $83.69 \pm 1.45$ \\
\hline $\mathrm{CaCO}_{3}(\%)$ & $1.49 \pm 0.02$ & $2.14 \pm 0.06$ & $0.65 \pm 0.03$ & $1.23 \pm 0.07$ \\
\hline Organik madde $(\%)$ & $1.44 \pm 0.07$ & $1.51 \pm 0.11$ & $1.96 \pm 0.09$ & $0.18 \pm 0.03$ \\
\hline $\mathrm{pH}^{\S}$ & $7.46 \pm 0.02^{\S}$ & $7.59 \pm 0.04^{\S}$ & $7.24 \pm 0.06^{\S}$ & $7.41 \pm 0.08^{\S}$ \\
\hline $\mathrm{EC}\left(\mathrm{mS} \mathrm{cm}^{-1}\right)^{\Psi}$ & $1.19 \pm 0.04^{\Psi}$ & $1.03 \pm 0.02^{\Psi}$ & $0.59 \pm 0.04^{\Psi}$ & $0.49 \pm 0.02^{\Psi}$ \\
\hline Tane yoğunluğu $\left(\mathrm{g} \mathrm{cm}^{-3}\right)$ & $2.67 \pm 0.02$ & $2.63 \pm 0.02$ & $2.66 \pm 0.02$ & $2.31 \pm 0.03$ \\
\hline Hacim ağırlığı $\left(\mathrm{g} \mathrm{cm}^{-3}\right)$ & $1.06 \pm 0.05$ & $1.17 \pm 0.03$ & $1.26 \pm 0.04$ & $0.72 \pm 0.04$ \\
\hline
\end{tabular}

$\S 1: 2.5$ (toprak:su) süspansiyonda belirlenmiştir.

${ }^{\Psi}$ Saturasyon ekstraktında belirlenmiştir.

\section{Denemenin kurulması}

Araştırmada kullanılan toprak örnekleri, araziden getirilerek laboratuvar şartlarında kurutulmuş ve 8 mm'lik elekten geçirilmiştir. Toprak örnekleri firın kuru ağırlık esasına göre kil tekstür sınıfi toprak için $14000 \mathrm{~g}$ (Toprak I), tın tekstür sınıfi toprak için $16000 \mathrm{~g}$ (Toprak II) ve kumlu tın tekstür sınıfı toprak için $17000 \mathrm{~g}$ (Toprak III) tartılmıştır. Toprak örneklerine $0.5 \mathrm{~mm}$ 'den elenmiş firın kuru ağırlık esasına dört farklı dozda (\%0, \%1, \%3 ve \%5) zeolit uygulanmış ve homojen karışımları sağlanmıştır. Toprak-zeolit karışımları $40 \quad \mathrm{~cm}$ uzunluğunda, $25 \mathrm{~cm}$ genişliğinde ve $15 \mathrm{~cm}$ derinliğindeki plastik kaplara yerleştirilmiştir. Denemede 3 toprak $\times 4$ doz $\times 3$ tekerrür olarak toplamda 36 örnek üzerinde çalışılmıştır. Plastik kaplara yerleştirilen toprak-zeolit karışımları yaklaşık tarla kapasitesi nem seviyesinde bağıl nemin $\% 60 \pm 5$ ve ortalama sicaklığın $25 \pm 2^{\circ} \mathrm{C}$ olduğu laboratuvar koşullarında 4 ay inkübasyona bırakılmıştır. İnkübasyon sürecinde örneklerin nem içerikleri sürekli olarak kontrol edilerek buharlaşmadan meydana gelen kayıplar için 3'er gün arayla tarla kapasitesinde olacak şekilde su ilavesi yapılmıştır. İnkübasyon periyodu sonrasinda deneme kaplarındaki topraklar yaklaşık tarla kapasitesi nem seviyesinde iken $100 \quad \mathrm{~cm}^{3}$ 'lük silindirler ile bozulmamış toprak örnekleri alınarak hacim ağırlığ 1 (HA), porozite ve hidrolik iletkenlik (HI) değerleri belirlenmiştir. Ayrıca, deneme toprakları hava kurusu nem seviyesine kadar kuruduğunda ise kürek ile bozulmuş toprak örnekleri alınarak agregat büyüklük dağılımı(ABD), ortalama ağırlık çap (OAÇ), agregat stabilitesi (AS) ve dispersiyon oranı (DO) değerleri belirlenmiştir. Araştırmada kullanılan zeolit dozları Xiubin and Zhanbin (2001), Sepaskhah and Barzegar
(2010), Razmi and Sepaskhah (2012), Susana et al. (2015) tarafından yapılan çalışma sonuçları değerlendirilerek belirlenmiştir.

\section{Analiz yöntemleri}

Tane büyüklük dağılımı Bouyoucos Hidrometre yöntemiyle (Gee and Bauder, 1986), katyon değişim kapasitesi sodyum asetatla $(1 \mathrm{~N}, \mathrm{pH}=8.2)$ sodyum adsorbsiyonu sağlandıktan sonra, amonyum asetatla $(1 \mathrm{~N}, \mathrm{pH}=7.0)$ ekstrakte edilen solusyonlarda alev fotometresiyle $\mathrm{Na}^{+}$okuması yapılarak belirlenmiştir (Rhoades, 1982a). Kireç içeriği Scheibler kalsimetresi kullanılarak (Nelson, 1982), organik madde içeriği Smith-Weldon yöntemiyle belirlenmiştir (Nelson and Sommers, 1982). pH ölçümleri 1:2.5 toprak:su süspansiyonunda (McLean, 1982), EC ölçümleri saturasyon macunundan elde edilen ekstraksiyon süzüklerinde elektriki kondüktivite aleti kullanılarak yapılmıştır (Rhoades, 1982b). Tane yoğunluğu piknometre yöntemiyle (Blake and Hartge, 1986a), hacim ağırlığı 100 $\mathrm{cm}^{3}$ 'lük bozulmamış örnekler alınarak belirlenmiştir (Blake and Hartge, 1986b). Tane yoğunluğu ve hacim ağırlığı değerleri kullanılarak porozite hesaplanmıştır (Danielson and Sutherland, 1986). Tarla kapasitesi basınçlı tablada $-0.033 \mathrm{MPa}$ basınç altında toprak örneklerinin hidrolik dengeye gelmesinden sonra hacim esasına göre belirlenmiştir (Cassel and Nielson, 1986). Kuru agregat büyüklük dağılımı Rotary eleği $(<0.42,0.42-0.84,0.84-2.0$, $2.0-6.4, \quad 6.4-12.7$ ve $>12.7 \mathrm{~mm})$ kullanılarak belirlenmiş ve daha sonra aşağıdaki eşitlik kullanılarak kuru ortalama ağırlık çap hesaplanmıştır (Kemper and Rosenau, 1986). 


$$
\mathrm{OAÇ}=\sum_{\mathrm{i}=1}^{\mathrm{n}} \overline{\mathrm{X}}_{\mathrm{i}} \cdot \mathrm{W}_{\mathrm{i}}
$$

$\mathrm{Xi}$ : Herbir agregat fraksiyonunun ortalama çapı, mm

Wi : Xi ortalama çaptaki büyüklük sınıfına ait agregatların oranı, $\%$

Agregat stabilitesi Yoder tipi sslak eleme aleti kullanılarak belirlenmiştir (Kemper and Rosenau, 1986). Örneklerinin dispers edilmesinden önce ve sonra kil+silt fraksiyonları hidrometre ile ölçülmüş ve aşağıdaki eşitlik kullanılarak dispersiyon oranı hesaplanmıştır (Lal, 1988).

DO $=\frac{\text { Süspansiyonda ölçülen toplam }(\text { kil }+ \text { silt })}{\text { Mekanik analizde ölçülen toplam }(\text { kil }+ \text { silt })} \times 100$

Hidrolik iletkenlik doygun koşullarda sabit su seviyeli permeametre yöntemi ile belirlenmiştir (Klute and Dirksen, 1986).

\section{İstatistiksel değerlendirme}

Muamele faktörlerinin incelenen parametreler üzerindeki etki değerlerini belirlemek için SPSS istatistik paket programı kullanılarak ANOVA ve Tukey'in çoklu karşılaştırma test yöntemi uygulanmışıtır. Ayrıca, zeolit uygulamalarının toprak özellikleri üzerine etkilerini değerlendirmek için $\mathrm{ABD}, \mathrm{OAÇ,} \mathrm{AS,} \mathrm{DO,} \mathrm{HA} \mathrm{ve} \mathrm{Hİ} \mathrm{değerleri} \mathrm{arasında}$ regresyon ve korelasyon analizleri yapılmıştır. (IBM, 2011).

\section{BULGULAR VE TARTIŞMA}

\section{Zeolit uygulamalarının incelenen toprak özellikleri üzerine etkileri}

\section{a. Agregat büyüklük dağılımı (ABD) ve ortalama ağırlıklı çap (OAÇ)}

Zeolit uygulamalarının agregat büyüklük dağılımı (ABD) ve ortalama ağılıklı çap (OAÇ) üzerine etkileri Çizelge 2'de verilmiştir. Araştırma toprağı I'e uygulanan zeolit dozu arttıkça $<0.42$, $0.42-0.84, \quad 0.84-2$ ve $2-6.4 \mathrm{~mm}$ agregat fraksiyonlarının miktarlarında kontrollerine göre önemli düzeyde artı̧lar meydana gelirken, 6.4-12.7 ve $>12.7 \mathrm{~mm}$ agregat fraksiyonlarının miktarlarında ise azalışların meydana geldiği belirlenmiştir. Zeolit uygulaması ile $6.4-12.7 \mathrm{~mm}$ agregat fraksiyonlarının miktarlarında meydana gelen azalışların istatistiksel olarak önemsiz olduğu belirlenirken, $>12.7 \mathrm{~mm}$ agregat fraksiyonlarının miktarlarında meydana gelen azalışların istatistiksel olarak önemli $(\mathrm{p}<0.05)$ olduğu tespit edilmiştir. Kontrol düzeyinde $>12.7 \mathrm{~mm}$ agregat fraksiyonu miktarı $\% 52.13$ 'den $\% 1, \% 3$ ve $\% 5$ zeolit uygulamaları sonrasında sirasıyla $\% 49.17$,
$\% 39.79$ ve $\% 15.35$ 'e düşmüştür. Toprak II'de $\% 1$ dozunda zeolit uygulamasinın $<0.42,0.42-0.84,0.84$ 2 ve $2-6.4 \mathrm{~mm}$ agregat fraksiyonlarını miktarların kontrole azalttığı, 6.4-12.7 ve >12.7 mm agregat fraksiyonların miktarlarını ise artırdığı belirlenmiştir. Söz konusu toprağa $\% 3$ ve $\% 5$ oranında zeolit uygulamaları ise $<0.42,0.42-0.84,0.84-2$ ve $2-6.4$ $\mathrm{mm}$ agregat fraksiyonlarının miktarlarını kontrole artırdı ̆̆ $1, \quad 6.4-12.7$ ve $>12.7 \quad \mathrm{~mm}$ agregat fraksiyonların miktarlarını ise azalttığı belirlenmiştir. Kumlu tın tekstür sinıfinda olan Toprak III'e uygulanan zeolitin $<0.42,0.42-0.84,0.84-2,2-6.4$ ve 6.4-12.7 mm agregat fraksiyonlarının miktarlarında azalışlara neden olduğu belirlenirken, $>12.7 \mathrm{~mm}$ agregat fraksiyonların miktarlarında artışlar sağladığı tespit edilmiştir. Toprak I, II ve III'ün kontrol örneklerinde $>12.7 \mathrm{~mm}$ agregat fraksiyonlarının miktarı $\% 52.13, \quad \% 23.53$ ve $\% 0.75$ olarak belirlenmiştir. Özellikle, toprak I'de yüksek kil içeriğinin neden olduğu yüksek kohezyon, inkübasyon süreci sonrasında kesek olarak nitelendirilebilecek 12.7 mm'den büyük agregasyon yapılarının oluşmasına neden olmuştur. Kil ve silt içeriği daha az, kum içeriği daha fazla olan toprak III'de büyük agregat oluşumu toprak I ve II'den çok daha az olmuştur. Zeolit uygulaması toprak I ve II'de büyük agregat oluşumunu azaltmış ve buna bağlı olarak söz konusu topraklarda OAÇ değerlerinin düşmesine neden olmuştur $(\mathrm{p}<0.05)$. Toprak III'de ise zeolit uygulaması büyük agregat oluşumunu artırmış ve buna bağlı olarak söz konusu toprakta OAÇ değerinin artmasına neden olmuştur. Genel ortalama verileri incelendiğinde de, zeolit uygulamaları $<0.42,0.42-0.84,0.84-2$ ve $2-6.4 \mathrm{~mm}$ agregat fraksiyonları miktarlarının kontrollerine göre daha yüksek, 6.4-12.7 ile >12.7 mm agregat fraksiyonlarının ise daha düşük olduğu görülmektedir. Zeolit uygulamasiyla büyük agregatların oranlarının azalması OAÇ değerlerini Toprak I'de 9.24 mm'den 5.06 mm'ye, Toprak II'de 5.16 mm'den 4.14 mm'ye düşürmüştür. Toprak III'de ise zeolit uygulaması ile OAÇ değeri 2.61 mm'den 2.77 mm'ye yükselmiştir. Genel ortalamada kontrol düzeyinde $5.67 \mathrm{~mm}$ olan OAÇ değeri zeolit uygulaması ile $4.17 \mathrm{~mm}$ 'ye düşmüştür $(\mathrm{p}<0.05)$. Zeolit ile OAÇ arasındaki korelasyon katsayıları Toprak I, II ve III için sırasıyla $-0.935^{* *},-0.465$ ve $0.587^{*}$ olarak belirlenirken, zeolit uygulaması ile OAÇ arasındaki genel korelasyon katsayısı -0.267 olarak belirlenmiştir. Topraklara uygulanan toprak düzenleyicilerin değişim komplekslerinde meydana getirdiği değişikliklerden dolayı büyük agregatların kırılmasına neden olabileceği belirtilmektedir (Whalen and Chang, 2002; Hurisso et al., 2013; Aksakal et al., 2016). 


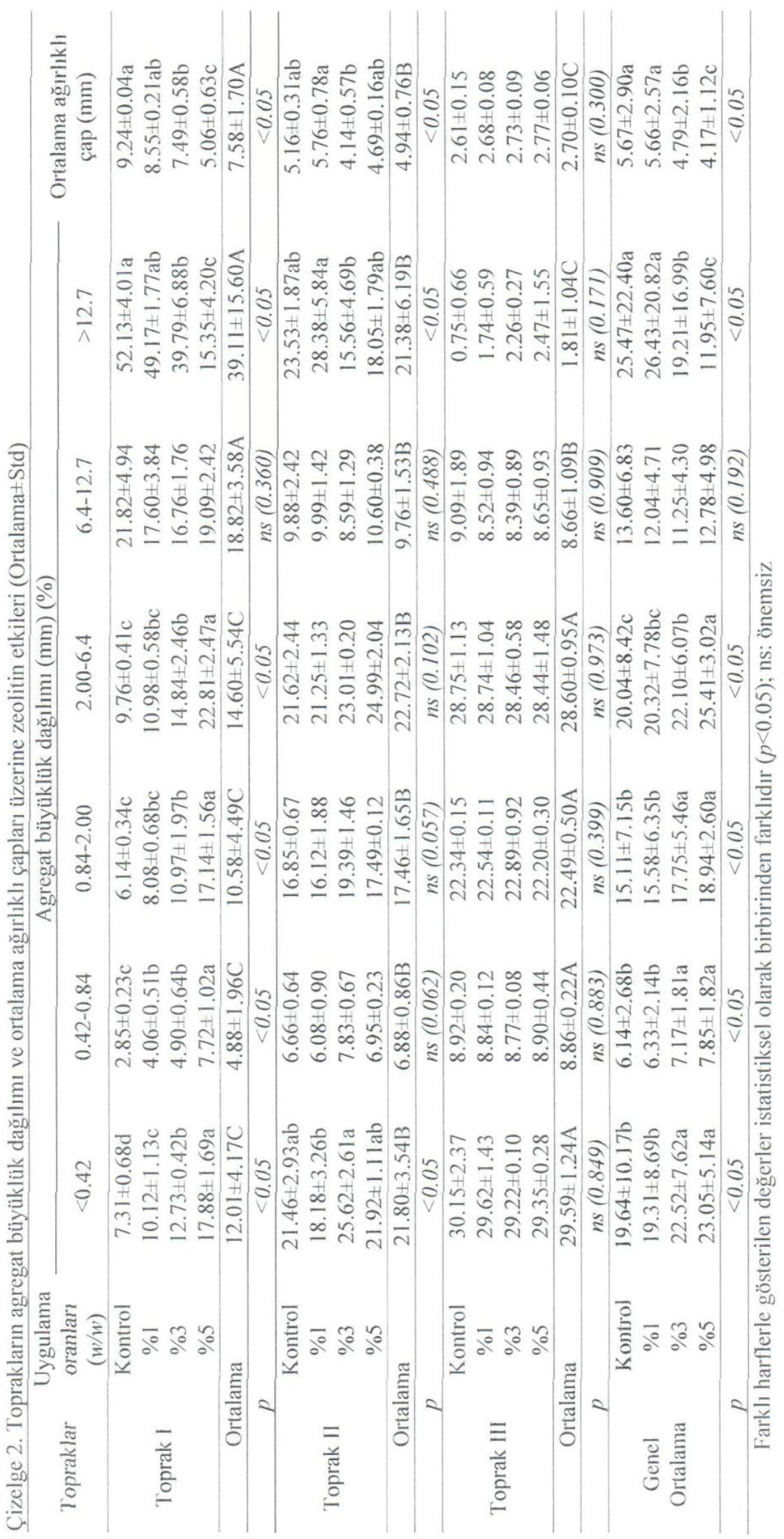


Bu sonuçlar, zeolitin Toprak I ve II gibi yüksek kil ve silt içeren topraklarda büyük agregat ve kesek oluşumunu azaltmak için kullanılabileceğini göstermektedir. Ayrıca, yüksek spesifik yüzeyi ve yüksek negatif elektrik yükü sayesinde Toprak III gibi yüksek kum içeriğine sahip topraklara uygulanan zeolitin agregatlaşmayı artırabileceği görülmektedir.

\section{b. Agregat stabilitesi (AS)}

Zeolit uygulamaları araştırma topraklarının tüm agregat fraksiyonlarında agregat stabilitesi (AS) değerlerini kontrollerine göre önemli düzeyde (p<0.05) artırmıştır (Çizelge 3; Şekil 1). Zeolitin agregat stabilitesi üzerine etkinliğinin genel olarak doz arttıkça artış gösterdiği belirlenmiştir. Kontrolleri ile karşılaştırıldığında, Toprak I > $12.7 \mathrm{~mm}$ ve Toprak III $<0.42,0.42-0.84,0.84-2$ ve $>12.7 \mathrm{~mm}$ agregat fraksiyonları dışındaki diğer agregat fraksiyonlarında en yüksek AS değerleri en yüksek uygulama dozu $\% 5$ 'de elde edilmiştir. Toprak I >12.7 mm ve Toprak III <0.42, 0.42-0.84, $0.84-2$ ve $>12.7 \mathrm{~mm}$ agregat fraksiyonlarında en yüksek AS değerleri \%3 uygulama dozunda elde edilmiştir. Zeolit uygulaması sonrasında elde edilen en yüksek AS değerleri kontrolleriyle karşılaştırıldığında Toprak I'de $<0.42$, $0.42-0.84,0.84-2,2-6.4,6.4-12.7$ ve $>12.7 \mathrm{~mm}$ agregat fraksiyonlarında AS değerlerindeki artış oranları sirasıyla \%126, 85, 76, 66, 85 ve 137 olarak belirlenmiştir. Söz konusu artış oranları Toprak II için \%50, 81, 40, 50, 55, 66 ve Toprak III için \%46, $18,57,69,49$ ve 84 olarak belirlenmiştir. Ortalama olarak Toprak I'de kontroldeki AS \%25.20 iken \%5 zeolit uygulama dozunda \%47.36 olarak belirlenmiş ve zeolit uygulaması AS'de \%88 oranında artış sağlamıştır. Toprak II'de ortalama AS değeri \%29.64'den \%46.10'a yükselerek \%56 oranında, Toprak III'de de kontrolde ortalama AS değeri $\% 25.10$ iken $\% 3$ uygulama dozunda AS değeri \%39.04'e yükselerek \%56 oranında artışın olduğu tespit edilmiştir. Genel ortalama AS değeri kontrolde \%26.64 iken zeolit uygulama dozlarının artışı ile artış göstermiş \%5 uygulama dozunda \%43.51 olarak belirlenmiş ve kontrole göre \%63 oranında artışın meydana geldiği belirlenmiştir. Zeolit uygulaması ile AS arasındaki korelasyon katsayısı Toprak I, II ve III için sirasıyla $0.953 * *, 0.955^{* *}$ ve $0.875 * *$ olarak belirlenirken, zeolit-AS arasındaki genel korelasyon katsayısı ise $0.867^{* *}$ olarak belirlenmiştir. Kırkık (2011) yapmış olduğu çalışmada, toprağa uygulanan farklı boyut ve dozlardaki zeolitin strüktür stabilite indeksi değerini \%16 oranında artırdığını ve toprakta agregatlaşmanın artış gösterdiğini tespit etmiştir.

\section{c. Dispersiyon oranı (DO)}

Zeolit uygulamalarının dispersiyon oranı (DO) değerlerine etkileri Çizelge 4 ve Şekil 1'de verilmiştir. Tüm toprakların farklı boyutlardaki agregat fraksiyonlarında en yüksek DO değerleri kontrol seviyelerinde belirlenmiştir. Zeolit uygulamaları ile DO değerlerinde genellikle önemli düzeyde düşüşler meydana gelmiştir $(\mathrm{p}<0.05)$. Toprak I'de en düşük DO değerleri $<0.42,6.4-12.7$ ve $>12.7 \mathrm{~mm}$ agregat fraksiyonlarında $\% 1$ uygulama dozunda belirlenirken; 0.42-0.84, 0.84-2 ve 2-6.4 mm agregat fraksiyonlarında $\% 3$ dozunda belirlenmiştir. Toprak I'in kontrol düzeyinde ortalama DO değeri $\% 24.13$ olarak belirlenirken en düşük ortalama DO değeri \%1 dozunda \%17.74 olarak belirlenmiş ve zeolit uygulaması DO değerinde kontrole göre $\% 26.5$ oranında azalış meydana getirmiştir. Toprak II'de zeolit uygulama dozu arttıkça tüm agregat boyutlarının DO değerlerinde azalışlar meydana gelmiş ve en düşük DO değerleri $\% 5$ uygulama dozunda belirlenmiştir. Toprak II'nin kontrol düzeyinde $<0.42,0.42-0.84,0.84-2,2-6.4,6.4-12.7$ ve $>12.7 \mathrm{~mm}$ agregat fraksiyonlarında DO değerleri sirasiyla \%57.47, \%49.29, \%40.87, \%39.22, \%43.74 ve $\% 41.65$ belirlenirken zeolit uygulaması sonrasında $\% 48.39, \% 36.94, \% 31.39, \% 27.96, \% 31.17$ ve \%35.42 olarak belirlenmiştir. Kontrolleri ile karşılaştırıldığında \%5 zeolit uygulaması sonrasında Toprak II'nin $<0.42,0.42-0.84,0.84-2,2-6.4$, 6.412.7 ve $>12.7 \mathrm{~mm}$ agregat fraksiyonlarında DO değerlerindeki azalış oranları sırasıyla \%15.8, 25.1, 23.2, 28.7, 28.7 ve 15.0 olarak belirlenmiştir. Toprak III'de en düşük DO değerleri <0.42, 0.42-0.84, 0.842 ve 2-6.4 $\mathrm{mm}$ agregat fraksiyonlarında $\% 5$ uygulama dozunda belirlenirken; 6.4-12.7 ve $>12.7$ $\mathrm{mm}$ agregat fraksiyonlarında $\% 3$ dozunda belirlenmiştir. Zeolit uygulaması sonrasında belirlenen en düşük DO değerleri kontrolleri ile kıyaslandığında \%20.6, 29.7, 31.6, 29.3, 17.2 ve 20.0 oranlarında düşüşlerin meydana geldiği belirlenmiştir. Ortalama olarak Toprak I'de kontroldeki DO \%24.13 iken \%1 zeolit uygulama dozunda \%17.74 olarak belirlenmiş ve zeolit uygulaması DO'da \%26.5 oranında azalış sağlamıştır. Toprak II'de ortalama DO değeri $\% 45.37$ 'den $\% 5$ zeolit uygulaması sonrasında $\% 35.21$ 'e düşerek \%22.4 oranında, Toprak III'de ise $\% 45.87$ 'den \%34.86'a düşerek \%24.0 oranında azalışların olduğu tespit edilmiştir. Genel ortalama DO değeri kontrolde \%38.46 iken zeolit uygulama dozlarının artışı ile düşüşler göstermiş \%5 uygulama dozunda \%30.20 olarak belirlenmiş ve kontrole göre \%21.5 oranında düşüşün meydana geldiği belirlenmiştir. 


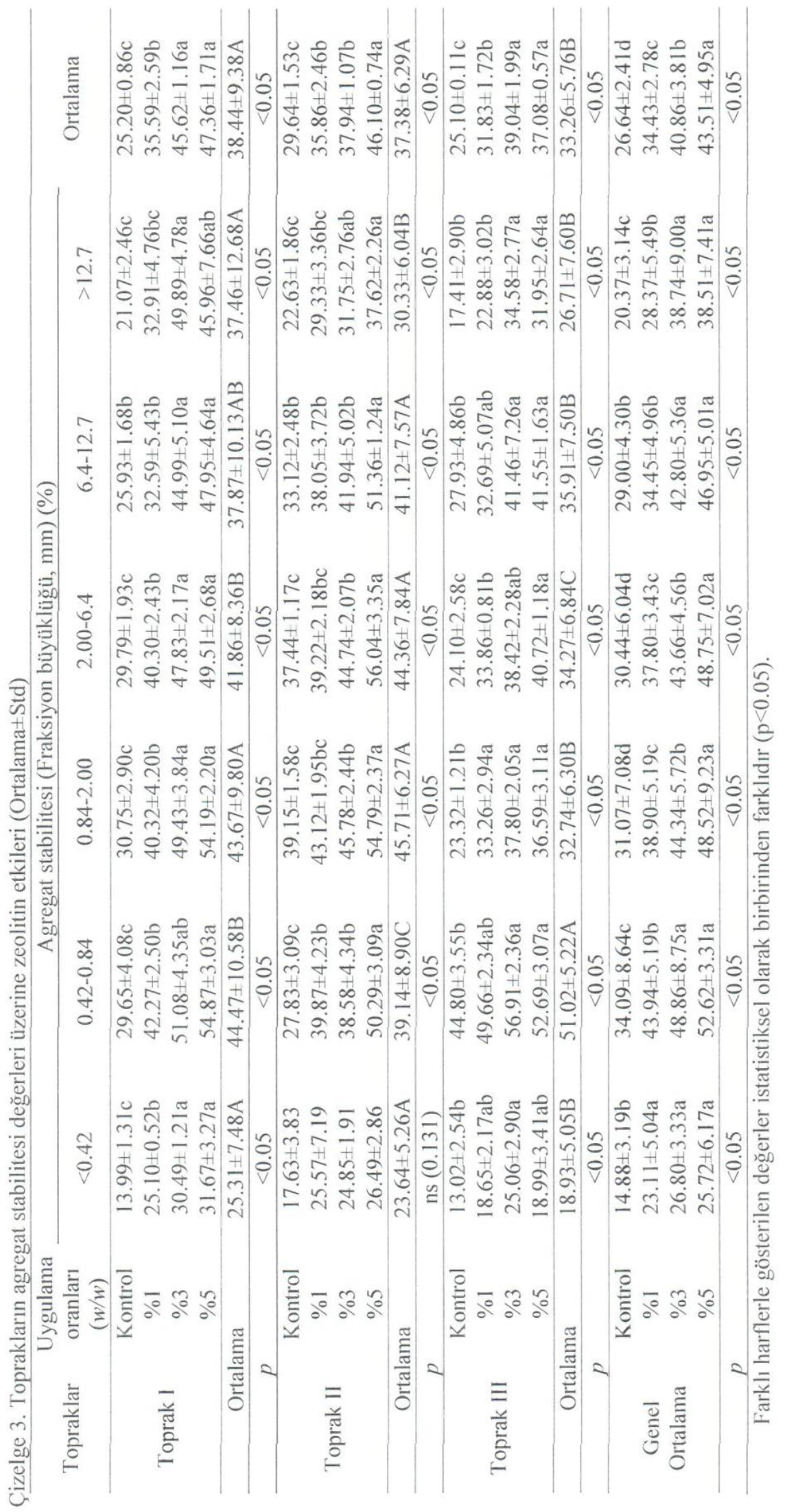




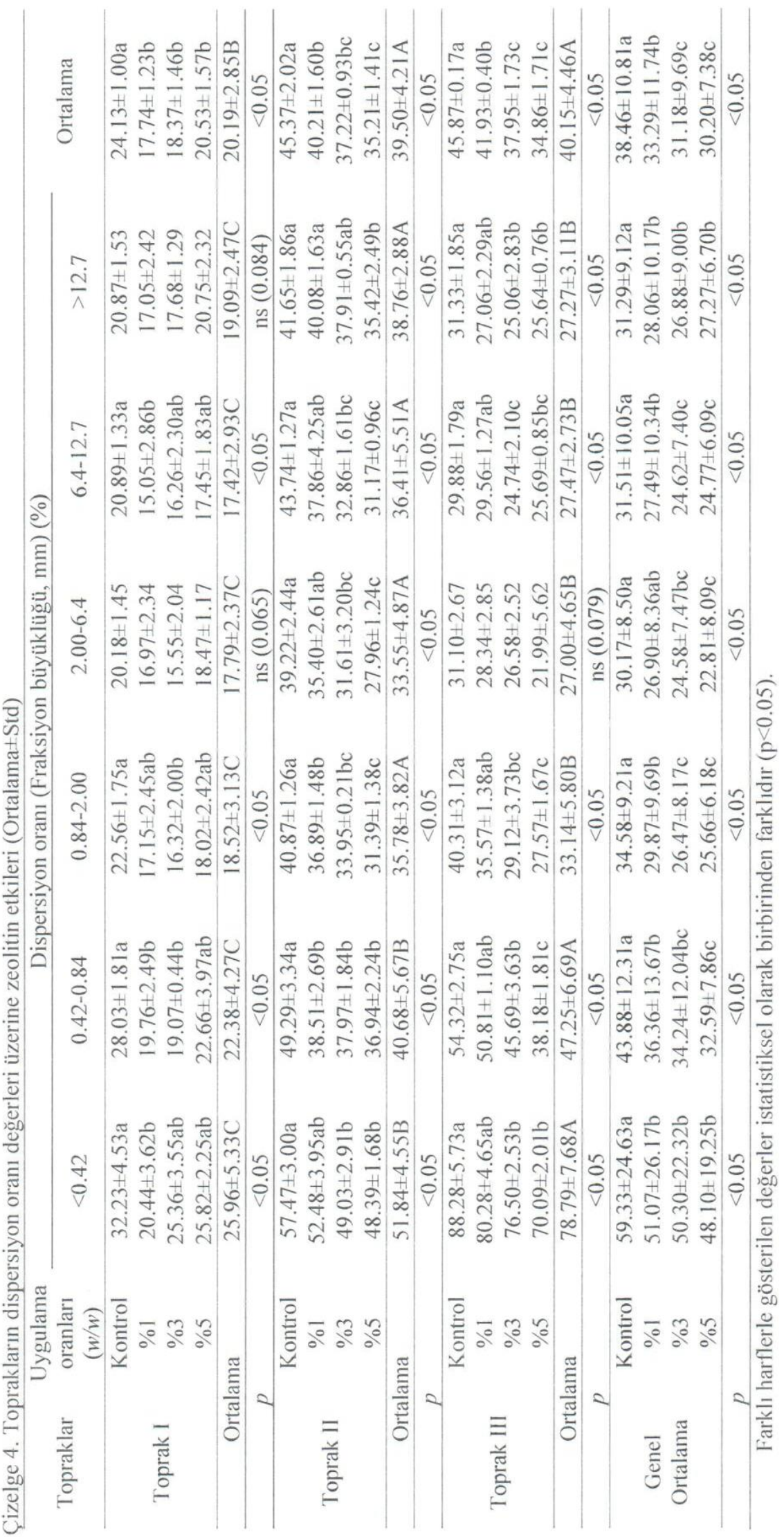




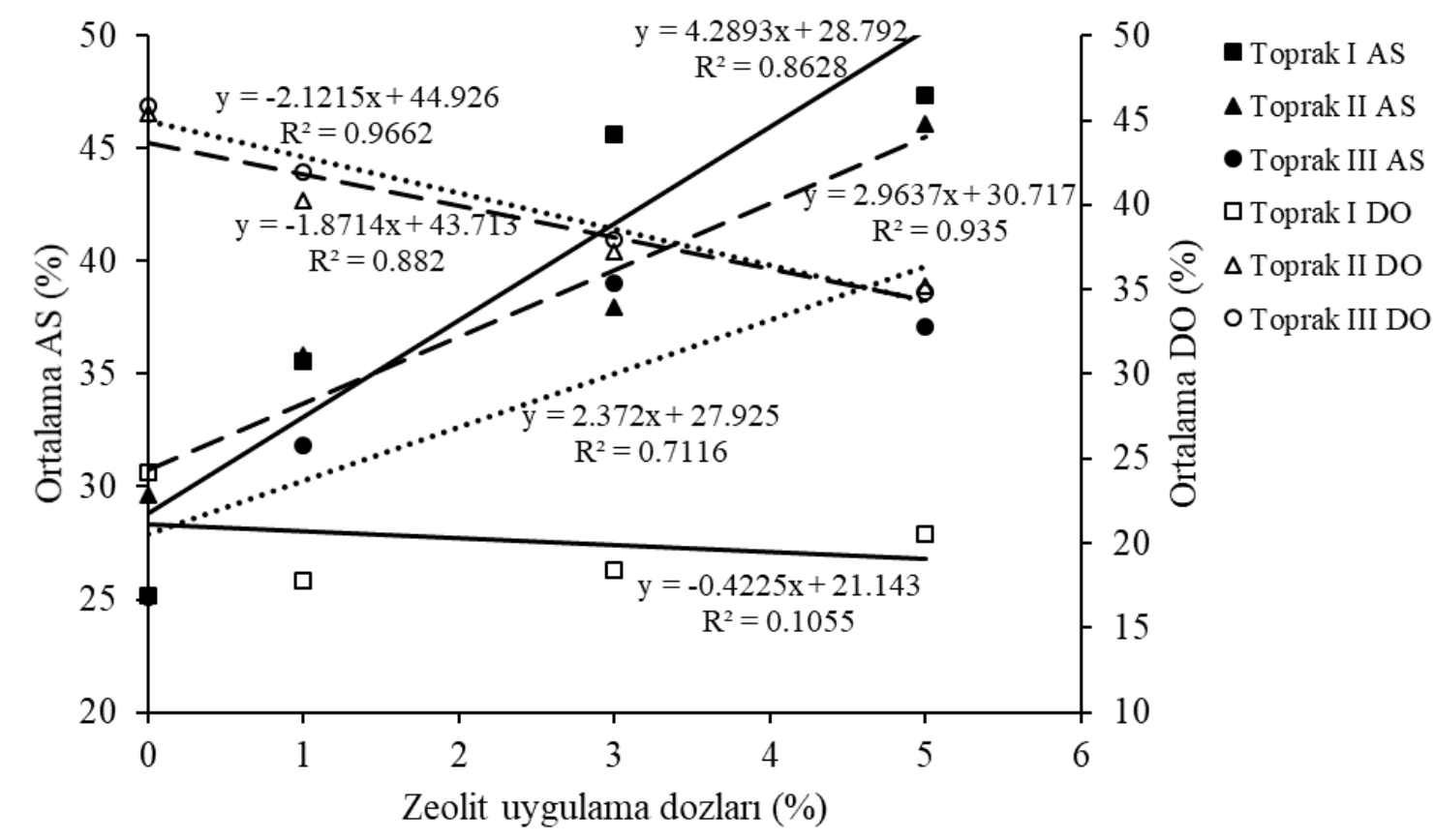

Şekil 1. Zeolit uygulama dozları ile ortalama agregat stabilitesi ve ortalama dispersiyon oranları arasındaki ilişkiler

Zeolit uygulaması ile DO arasındaki korelasyon katsayısı Toprak I, II ve III için sırasıyla -0.417 , $0.929 * *$ ve $-0.970 * *$ olarak belirlenirken, zeolit-DO arasındaki genel korelasyon katsayısı ise -0.301 olarak belirlenmiştir. Söz konusu bu ilişkilerin toprakların AS değerleri ile uyumlu oldukları tespit edilmiştir. Dispersiyon oranı ile AS arasında önemli düzeyde negatif korelasyon belirlenmiştir. Dispersiyon oranı ile AS arasındaki korelasyon katsayıları Toprak I, II ve III için sırasıyla -0.612*, $0.914 * *$ ve $-0.857 * *$ olarak belirlenirken, DO-AS arasındaki genel korelasyon katsayıs1 -0.452** olarak belirlenmiştir. Gülser (2006), Opara (2009), Aksakal et al. (2016) tarafından yapılan araştırmalarda da benzer sonuçların elde edildiği görülmektedir.

\section{d. Hacim ağırlığı (HA)}

Zeolit uygulamalarının araştırma konusu toprakların hacim ağırlıklarını (HA) istatistiksel olarak önemli $(p<0.05)$ ölçüde düşürdüğü ve uygulama dozu arttıkça hacim ağırlığında düşüşlerin meydana geldiği belirlenmiştir (Çizelge 5; Şekil 2). Toprak I'in kontrol seviyesindeki HA değeri $1.06 \mathrm{~g}$ $\mathrm{cm}^{-3}$ iken, \%1, 3 ve 5 zeolit uygulama dozları sonrasında $0.98,0.96$ ve $0.96 \mathrm{~g} \mathrm{~cm}^{-3}$ olarak belirlenmiştir. Kontrolü ile kıyaslandığında \%1 uygulama dozu sonrasında toprağın HA değerinde $\% 7.5$ oranında, $\% 3$ ve $\% 5$ uygulama dozu sonrasında \%9.4 oranında düşüşlerin meydana geldiği hesaplanmıştır. Toprak II ve III'ün kontrol seviyelerinde HA değerleri sırasıyla $1.17 \mathrm{~g} \mathrm{~cm}^{-3}$ ve $1.26 \mathrm{~g} \mathrm{~cm}^{-3}$ olarak belirlenirken, uygulamalar sonrasında en düşük HA değerleri $\% 5$ uygulama dozunda $1.10 \mathrm{~g} \mathrm{~cm}^{-3}$ ve $1.13 \mathrm{~g} \mathrm{~cm}^{-3}$ olarak belirlenmiştir. Toprak II ve III'de $\% 5$ zeolit uygulaması sonrasında HA değerlerinde kontrollerine göre \%6.0 ve \%10.3 oranlarında düşüşlerin meydana geldiği tespit edilmiştir. Genel ortalamada, kontrol seviyesinde HA değeri $1.16 \mathrm{~g} \mathrm{~cm}^{-3}$ iken $\% 1,3$ ve 5 zeolit uygulamaları sonrasında $1.10,1.08$ ve $1.06 \mathrm{~g}$ $\mathrm{cm}^{-3}$ olarak ölçülmüş olup oransal olarak \%5.2, \%6.9 ve \%8.6 düşüşlerin meydana geldiği hesaplanmıştır. Zeolit ile HA arasında arasındaki korelasyon katsayıları Toprak I, II ve III için sırasıyla -0.728**, $0.747 * *$ ve $-0.836 * *$ olarak belirlenirken, zeolit-HA arasındaki genel korelasyon katsayıs $-0.374 *$ olarak belirlenmiştir. Topraklara uygulanan toprak düzenleyicilerin HA değerlerini düşürdüğü Shirani vd., (2002); Blanco-Canqui and Lal (2004); Angın (2008); Candemir and Gülser (2011); Aksakal vd., (2016) tarafından yapılan araştırmalar tarafindan da bildirilmektedir. Kırkık (2011) yapmış olduğu çalışmada, toprağa uygulanan zeolitin hacim ağırlığı değerini \%6.9 oranında düşürdüğünü tespit etmiştir.

\section{e. Porozite}

Zeolit uygulamaları araştırma konusu toprakların porozitelerini önemli ölçüde $(\mathrm{p}<0.05)$ artırdığı, uygulama dozu artışı ile poroziteki artışın daha fazla meydana geldiği belirlenmiş olup en 
yüksek porozite değerleri en yüksek uygulama dozunda (\%5) elde edilmiştir. Toprak I'in kontrol seviyesinde porozite $\% 60.30$ iken $\% 1,3$ ve 5 zeolit uygulama dozları sonrasinda \%63.42, \%63.92 ve \%64.04'e yükseldiği belirlenmiştir. Kontrolü ile kıyaslandığında \%5 uygulama dozu sonrasında toprağın porozitesinde \%6.2 oranında artışın meydana geldiği hesaplanmıştır. Kontrolleri ile kıyaslandığında Toprak II ve III'de \%5 zeolit uygulamas1 sonrasinda porozite $\% 4.5$ ve $\% 9.3$ oranlarında artışların meydana geldiği belirlenmiştir. Genel ortalamada, kontrol seviyesinde porozite $\% 56.19$ iken $\% 1,3$ ve 5 zeolit uygulamaları sonrasinda $\% 58.61, \quad \% 59.11$ ve $\% 59.91$ 'e yükselmiştir (Çizelge 5; Şekil 2). Kırkık (2011) yapmış olduğu çalışmada, toprağa uygulanan zeolitin poroziteyi ortalama olarak \%5.5 oranında artırdığını tespit etmiştir. Zeolit ile porozite arasında arasındaki korelasyon katsayıları Toprak I, II ve III için sırasıyla $0.728 * *, 0.747 * *$ ve $0.837 * *$ olarak belirlenirken, zeolit-porozite arasındaki genel korelasyon katsayısı $0.361 *$ olarak belirlenmiştir. Topraklara ilave edilen toprak düzenleyicilerin toprakların hacim ağırlığ1 değerlerini düşürdüğü ve porozitelerini artırdığ 1 yönündeki bulgular Haynes and Naidu (1998); Blanco-Canqui and Lal (2004); Gülser (2006); Angın (2008); Aksakal et al. (2016) tarafindan yapılan araştırma sonuçları ile örtüşmektedir.

Çizelge 5. Toprakların hacim ağırlığı, porozite ve hidrolik iletkenlik değerleri üzerine zeolitin etkileri (Ortalama \pm Std)

\begin{tabular}{|c|c|c|c|c|}
\hline Topraklar & $\begin{array}{c}\text { Uygulama } \\
\text { oranlar1 }(w / w)\end{array}$ & $\begin{array}{l}\text { Hacim ağırlı } \breve{g}_{1} \\
\left(\mathrm{~g} \mathrm{~cm}^{-3}\right)\end{array}$ & $\begin{array}{l}\text { Porozite } \\
(\%)\end{array}$ & $\begin{array}{l}\text { Hidrolik iletkenlik } \\
\left(\mathrm{cm} \mathrm{h}^{-1}\right)\end{array}$ \\
\hline \multirow{4}{*}{ Toprak I } & Kontrol & $1.06 \pm 0.05 a$ & $60.30 \pm 1.72 b$ & $8.58 \pm 2.73 b$ \\
\hline & $\% 1$ & $0.98 \pm 0.02 b$ & $63.42 \pm 0.78 \mathrm{a}$ & $13.29 \pm 5.04 \mathrm{ab}$ \\
\hline & $\% 3$ & $0.96 \pm 0.04 b$ & $63.92 \pm 1.31 \mathrm{a}$ & $15.24 \pm 4.67 \mathrm{ab}$ \\
\hline & $\% 5$ & $0.96 \pm 0.01 \mathrm{~b}$ & $64.04 \pm 0.38 \mathrm{a}$ & $21.05 \pm 5.79 \mathrm{a}$ \\
\hline \multicolumn{2}{|c|}{ Ortalama } & $0.99 \pm 0.05 \mathrm{C}$ & $62.92 \pm 1.88 \mathrm{~A}$ & $14.54 \pm 6.15 \mathrm{~B}$ \\
\hline \multicolumn{2}{|c|}{$p$} & $<0.05$ & $<0.05$ & $<0.05$ \\
\hline \multirow{4}{*}{ Toprak II } & Kontrol & $1.17 \pm 0.03$ & $55.64 \pm 1.16$ & $25.65 \pm 12.95$ \\
\hline & $\% 1$ & $1.15 \pm 0.03$ & $56.14 \pm 1.16$ & $34.96 \pm 10.03$ \\
\hline & $\% 3$ & $1.13 \pm 0.03$ & $57.03 \pm 1.14$ & $37.76 \pm 9.22$ \\
\hline & $\% 5$ & $1.10 \pm 0.01$ & $58.17 \pm 0.39$ & $46.17 \pm 8.08$ \\
\hline \multicolumn{2}{|c|}{ Ortalama } & $1.14 \pm 0.03 \mathrm{~B}$ & $56.75 \pm 1.33 \mathrm{~B}$ & $36.14 \pm 11.60 \mathrm{~A}$ \\
\hline \multicolumn{2}{|c|}{$p$} & $n s(0.066)$ & $n s(0.066)$ & $n s(0.185)$ \\
\hline \multirow{4}{*}{ Toprak III } & Kontrol & $1.26 \pm 0.04 \mathrm{a}$ & $52.63 \pm 1.35 b$ & $30.12 \pm 11.07$ \\
\hline & $\% 1$ & $1.16 \pm 0.02 b$ & $56.27 \pm 0.58 \mathrm{a}$ & $32.88 \pm 10.84$ \\
\hline & $\% 3$ & $1.16 \pm 0.02 b$ & $56.39 \pm 0.65 a$ & $38.53 \pm 15.02$ \\
\hline & $\% 5$ & $1.13 \pm 0.02 b$ & $57.52 \pm 0.75 a$ & $47.91 \pm 12.70$ \\
\hline \multicolumn{2}{|c|}{ Ortalama } & $1.18 \pm 0.05 \mathrm{~A}$ & $55.70 \pm 2.06 \mathrm{~B}$ & $37.36 \pm 12.83 \mathrm{~A}$ \\
\hline \multicolumn{2}{|c|}{$p$} & $<0.05$ & $<0.05$ & $n s(0.376)$ \\
\hline \multirow{4}{*}{ Genel Ortalama } & Kontrol & $1.16 \pm 0.09 \mathrm{a}$ & $56.19 \pm 3.57 b$ & $21.45 \pm 13.09 b$ \\
\hline & $\% 1$ & $1.10 \pm 0.09 b$ & $58.61 \pm 3.69 a$ & $27.04 \pm 12.96 \mathrm{ab}$ \\
\hline & $\% 3$ & $1.08 \pm 0.10 \mathrm{~b}$ & $59.11 \pm 3.73 a$ & $30.51 \pm 14.64 \mathrm{ab}$ \\
\hline & $\% 5$ & $1.06 \pm 0.08 b$ & $59.91 \pm 3.15 \mathrm{a}$ & $38.37 \pm 15.31 \mathrm{a}$ \\
\hline \multicolumn{2}{|c|}{$p$} & $<0.05$ & $<0.05$ & $<0.05$ \\
\hline
\end{tabular}

Farklı harflerle gösterilen değerler istatistiksel olarak birbirinden farklıdır $(\mathrm{p}<0.05)$.

\section{f. Hidrolik iletkenlik (Hi)}

Araştırma konusu toprakların hidrolik iletkenlik (HI) değerlerinde zeolit uygulamaları sonrasında kontrollerine göre artışlar belirlenmiştir. Söz konusu artışların Toprak II ve III'de istatistiksel olarak önemsiz olduğu, Toprak I'de ise önemli seviyede $(p<0.05)$ olduğu tespit edilmiştir (Çizelge 5). Zeolit uygulama dozları arttıkça Hİ değerlerinde genellikle artışlar olduğu ve en yüksek Hİ değerleri en yüksek uygulama dozu \%5'de elde edilmiştir. Toprak I'in kontrol seviyesinde Hİ $8.58 \mathrm{~cm} \mathrm{~h}^{-1}$ iken $\% 1,3$ ve 5 zeolit uygulama dozları sonrasinda $13.29,15.24$ ve $21.05 \mathrm{~cm} \mathrm{~h}^{-1}$ 'e yükseldiği belirlenmiştir. Kontrolü ile kıyaslandığında \%5 uygulama dozu sonrasında toprağın Hİ değerinde \%145.3 oranında artışın meydana geldiği hesaplanmıştır. Toprak II'de \%5 dozunda elde edilen en yüksek HI değeri $(46.17 \mathrm{~cm}$ $\mathrm{h}^{-1}$ ) kontrolü ile kıyaslandığında $\% 80.0$ oranında, Toprak III'de en yüksek Hİ değeri $\left(47.91 \mathrm{~cm} \mathrm{~h}^{-1}\right)$ kontrolü ile kıyaslandığında \%59.1 oranında artışın 
meydana geldiği belirlenmiştir. Genel ortalamada, kontrol seviyesinde Hİ değeri $21.45 \mathrm{~cm} \mathrm{~h}^{-1}$ iken $\% 1$, 3 ve 5 zeolit uygulamaları sonrasinda 27.04, 30.51 ve $38.37 \mathrm{~cm} \mathrm{~h}^{-1}$ 'e yükseldiği, oransal olarak en fazla artışın \%5 uygulama dozunda \%78.9 oranında olduğu belirlenmiştir. Razmi and Sepaskhah (2012) siltli kil tekstür sınıfındaki toprağa farklı oranlarda uyguladıkları zeolitin hidrolik iletkenliği önemli düzeyde artırdığını, en fazla artışın \%130 oranında 8 $\mathrm{g} / \mathrm{kg}$ uygulama dozunda meydana geldiğini belirtmektedirler. Hidrolik iletkenlik değerlerinde meydana gelen bu artışların, agregasyonun ve agregat stabilitesinin iyileşmesi, hacim ağırlığındaki azalma ve porozitedeki artış ile ilişkili olduğu Hati et al.
(2007), Angın (2008), Aksakal et al. (2016) tarafından bildirilmektedir. Toprak I için Hİ ile zeolit, AS, HA, porozite arasındaki korelasyon katsayıları sirasiyla $0.747 * *, 0.753 * *,-0.800 * *$ ve 0.800 olarak belirlenmiştir. Toprak II için söz konusu katsayılar 0.648*, 0.703*, -0.926, 0.926 olarak, Toprak III için $0.537,0.353,-0.684 * 0.683$ olarak belirlenmiştir. Moritani et al. (2010) tuzlu-sodik topraklara \%10 zeolit ilavesinin ortalama ağırlık çap değerini \%22.4 ile \%59.4 arasında, agregat stabilitesini 1.9 ile 3.9 kat arasında ve hidrolik iletkenliği 2 ile 2.5 kat arasında artırdığını belirlemişlerdir.

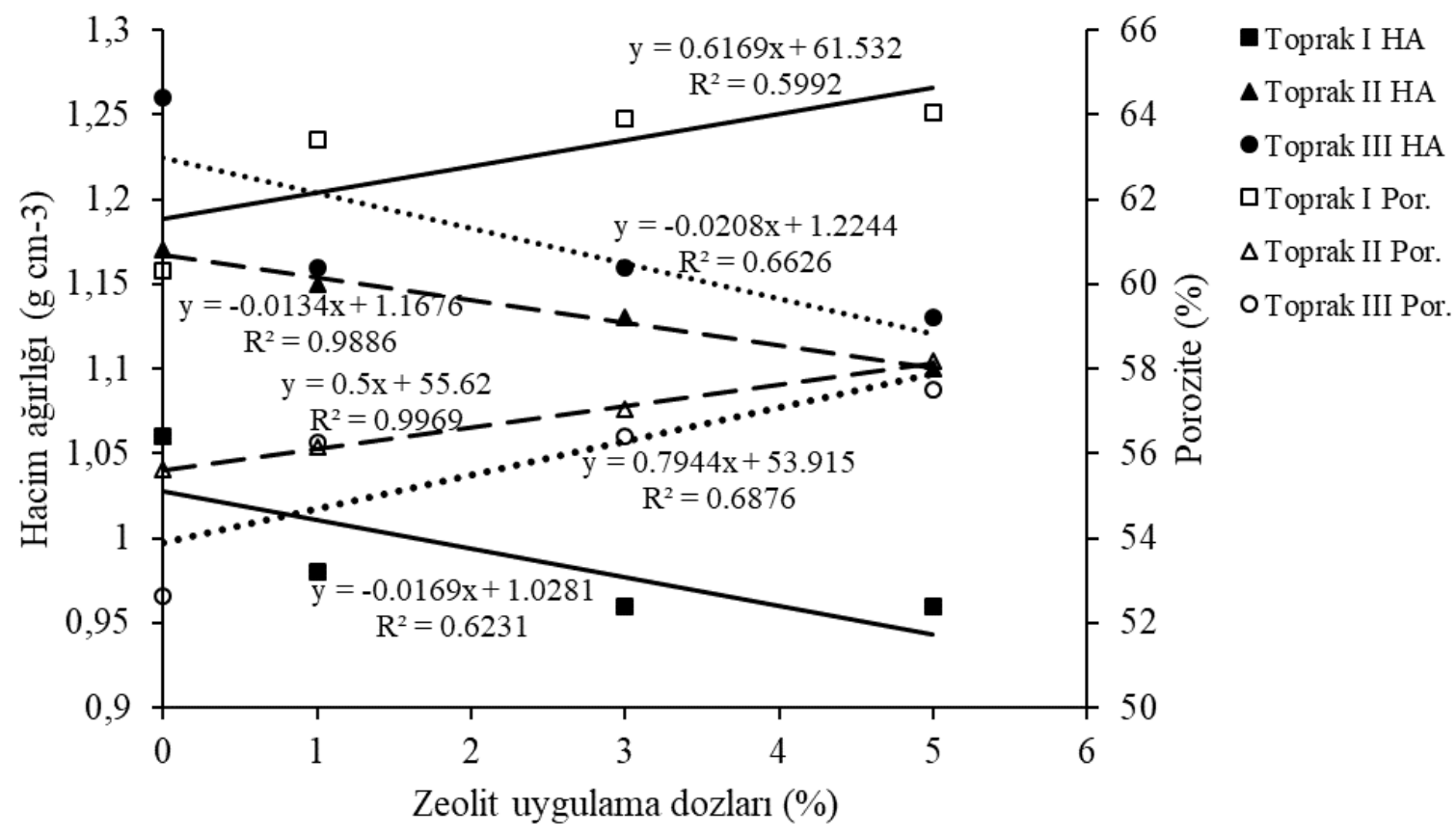

Şekil 2. Zeolit uygulama dozları ile hacim ağırlığı ve porozite arasındaki ilişkiler

\section{SONUÇ}

Farklı tekstür sınıfındaki topraklara zeolit uygulamasının yapıldığı bu çalışmada; zeolit uygulaması kil ve tın tekstür sınıfındaki topraklarda büyük agregat oluşumunu azaltmış ve buna bağlı olarak söz konusu topraklarda ortalama ağırlıklı çap değerlerinin düşmesine neden olmuştur. Kumlu tın tekstür sınıfındaki toprakta ise büyük agregat oluşumunu artırmış ve buna bağlı olarak söz konusu toprakta ortalama ağırlıklı çap değerinin artmasına neden olmuştur. Genel olarak; zeolit uygulamaları $<0.42,0.42-0.84,0.84-2$ ve $2-6.4 \mathrm{~mm}$ agregat fraksiyonları miktarlarının kontrollerine göre daha yüksek, 6.4-12.7 ile >12.7 $\mathrm{mm}$ agregat fraksiyonlarının ise daha düşük olduğu görülüştür.

Zeolit uygulamaları araştırma topraklarının tüm agregat fraksiyonlarında agregat stabilitesi değerlerini kontrollerine göre önemli düzeyde artırmıştır. Agregat stabilitesi üzerine etkinliğin genel olarak doz arttıkça artış gösterdiği belirlenmiştir. Tüm toprakların farklı boyutlardaki agregat fraksiyonlarında en yüksek dispersiyon oranı değerleri kontrol seviyelerinde belirlenirken, zeolit uygulamaları ile dispersiyon oranı değerlerinde genellikle önemli düzeyde düşüşler meydana gelmiştir. Zeolit uygulamaları araştırma konusu toprakların hacim ağırlıklarını önemli ölçüde düşürürken porozite ile hidrolik iletkenlik değerlerini artırmıştır.

Toprakta agregasyonun artırılması ve fiziksel özelliklerin iyileştirilmesi bitkiler için daha iyi bir gelişme ortamı sağlamasının yanında toprakların mekaniksel kuvvetlere ve erozyona karşı direncini artırmaktadır. Zeolit uygulaması topraklarda 
agregasyonu ve agregat stabilitesini geliştirmiş, özellikle kesekleşmeyi azaltarak tohum çıkışı ve kök gelişimini teşvik edecek yönde iyileşme sağlamıştır. Uygulama sonrasında hacim ağırlığının düşmesi ve porozite ile hidrolik iletkenliğin artması toprak gözenekliliğinin arttığının göstergesi olup; toprak içerisinde bitki kök gelişimini ve hava ile su hareketini olumlu yönde etkileyecektir. Sonuç olarak; zeolit toprak fiziksel kalite parametrelerinin iyileştirilmesi ve toprakların erozyona karşı daha dirençli hale getirilmesi için mineral toprak düzenleyici olarak kullanılabilir.

\section{KAYNAKLAR}

Abdi, G.H., Khui, M.K., Eshghi, S., 2006. Effects on natural zeolite on growth and flowering on strawberry. International Journal of Agricultural Research, 1: 384-389.

Aksakal, E.L., Sari, S., Angin, I., 2016. Effects of vermicompost application on soil aggregation and certain physical properties. Land Degrad. Develop., 27: 983-995.

Allen E., Ming, D., Hossner, L., Henninger, D., Galindo, C., 1995, Growth and nutrient uptake of wheat in a clinoptilolite-phosphate rock substrate, Agronomy Journal, 87: 1052-1059.

Angın, İ., 2008. Arıtma Çamurlarının Fiziksel ve Kimyasal Toprak Düzenleyicisi Olarak Kullanımı. Atatürk Üniversitesi Fen Bilimleri Enstitüsü Tarımsal Yapılar ve Sulama Anabilim Dalı Doktora Tezi, Erzurum, 96 s.

Bansiwal, A.K., Rayalu, S.S., Labhasetwar, N.K., Juwarkar, A.A., Devotta, S., 2006. Surfactantmodified zeolite as a slow release fertilizer for phosphorus. Journal of Agricultural and Food Chemistry, 54: 4773-4779.

Blake, G.R., Hartge, K.H., 1986a. Particle Density. Methods of Soil Analysis.Part 1. Physical and Mineralogical Methods. 2nd Edition. Agronomy No: 9, 377-382, 1188 p, Madison, Wisconsin USA.

Blake, G.R., Hartge, K.H., 1986b. Bulk Density. Methods of Soil Analysis.Part 1. Physical and Mineralogical Methods. 2nd Edition. Agronomy No: 9, 363-375, 1188 p, Madison, Wisconsin USA.

Blanco-Canqui H, Lal R. 2004. Mechanisms of carbon sequestration in soil aggregates. Critical Reviews in Plant Sciences, 23 (6): 481-504.

Bronick, C.J., Lal, R., 2005. Soil structure and management: a review. Geoderma, 124: 3-22.

Candemir F, Gülser C. 2011. Effects of different agricultural wastes on some soil quality indexes in clay and loamy sand fields. Communications in Soil Science and Plant Analysis, 42: 13-28.
Cassel, D.K., Nielsen, D.R., 1986. Field Capacity and Available Water Capacity, in: Klute, A. (Ed.), Methods of Soil Analysis. Part 1, Physical and Mineralogical Methods. ASA, SSSA, Agronomy No: 9, Madison, WI: pp. 901926.

Chander, K., Joergensen, R.G., 2002. Decomposition of ${ }^{14} \mathrm{C}$ labelled glucose in a $\mathrm{Pb}$-contaminated soil remediated with synthetic zeolite and other amendments. Soil Biology and Biochemistry, 34: 643-649.

Chon, H., Woo, S.I., Park, S.E., 1996. Recent Advences and New Horizons in Zeolite Science and Techhnology. Elsevier Science B.V., Amsterdam, The Netherlands

Danielson, R.E., Sutherland, P.L., 1986. Porosity. Methods of Soil Analysis.Part 1. Physical and Mineralogical Methods. 2nd Edition. Agronomy No: 9, 443-461, 1188 p, Madison, Wisconsin USA.

DeSutter, T.M., Pierzynski, G.M., 2005. Evaluation of soils for use as liner materials: A soil chemistry approach. Journal of Environmental Quality, 34: 951-962.

Dwyer, J., Dyer, A., 1984. Zeolites-An introduction. Chemistry and Industry, 2: 237-240.

Gee, G.W., Bauder, J.W., 1986. Particle-Size Analysis. Methods of Soil Analysis.Part 1. Physical and Mineralogical Methods. 2nd Edition. Agronomy No: 9, 383-411, 1188 p, Madison, Wisconsin USA.

Gülser, C., 2006. Effect of forage cropping treatments on soil structure and relationships with fractal dimensions. Geoderma, 131: 33-44.

Hati, K.M., Biswas, A.K., Bandyopadhyay, K.K., Misra, A.K., 2007. Soil properties and crop yields on a vertisol in India with application of distillery effluent. Soil and Tillage Research, 92: 60-68.

Haynes, R.J., Naidu, R., 1998. Influence of lime, fertilizer and manure applications on soil organic matter content and soil physical conditions: a review. Nutrient Cycling in Agroecosystems, 51: 123-137.

Hosseinpur, A.R., Kiani Sh., Halvaei, M., 2012. Impact of municipal compost on soil phosphorus availability and mineral phosphorus fractions in some calcareous soils. Environmental Earth Sciences, 67 (1): 91-96.

Hurisso, T.T., Davis, J.G., Brummer, J.E., Stromberger, M.E., Mikha, M.M., Haddix, M.L., Booher, M.R., Paul, E.A., 2013. Rapid changes in microbial biomass and aggregate size distribution in response to changes in organic matter management in grass pasture. Geoderma, 193-194: 68-75. 
IBM, 2011. IBM Statistics for Windows, version 20.0. IBM Corporation. Armonk, NY.

Kemper, W.D., Rosenau, R.C., 1986. Aggregate Stability and Size Distribution. Methods of Soil Analysis.Part 1. Physical and Mineralogical Methods. 2nd Edition. Agronomy No: 9. 425442, 1188 p, Madison, Wisconsin USA.

Kırkık, E.B., 2011. Doğal Zeolit Uygulamasının Bazı Toprak Özellikleri Üzerine Etkisi. Ege Üniversitesi Fen Bilimleri Enstitüsü, Toprak Bilimi ve Bitki Besleme Anabilim Dalı, Yüksek Lisans Tezi, İzmir, 91 sayfa.

Kithome, M., Paul, J.W., Lavkulich, L.M., Bomke, A.A., 1998. Kinetics of ammonium adsorption and desorption by the natural zeolite clinoptilolite. Soil Sciences Society of American Journal, 62: 622-629.

Klute, A., Dirksen, C., 1986. Hydraulic Conductivity and Diffusivity: Laboratory Methods. Methods of Soil Analysis.Part 1. Physical and Mineralogical Methods. 2nd Edition. Agronomy No: 9, 687-734, 1188 p, Madison, Wisconsin USA.

Lal, R., 1988. Soil Erosion Research Methods. Soil and Water Conservation Society, Iowa-USA.

Leggo, P.J., 2000, An investigation of plant growth in an organo-zeolitic substrate and its ecological significance. Plant and Soil, 219: 135-146.

McLean, E.O., 1982. Soil pH and Lime Requirement. Methods of Soil Analysis.Part 2. Chemical and Microbiological Properties. 2nd Edition. Agronomy No: 9, 199-224, 1159 p, Madison, Wisconsin USA.

Moritani, S., Yamamoto, T., Andry, H., Inoue, M., Yuya, A., Kaneuchi, T., 2010. Effectiveness of artificial zeolite amendment in improving the physicochemical properties of saline-sodic soils characterised by different clay mineralogies. Australian J. of Soil Research, 48: 470-479.

Nelson, D.W., Sommers, L.E., 1982. Total Carbon, Organic Carbon, and Organic Matter. Methods of Soil Analysis.Part 2. Chemical and Microbiological Properties. 2nd Edition. Agronomy No: 9, 539-579, 1159 p, Madison, Wisconsin USA.

Nelson, R.E., 1982. Carbonate and Gypsum. Methods of Soil Analysis.Part 2. Chemical and Microbiological Properties. 2nd Edition. Agronomy No: 9, 181-197, 1159 p, Madison, Wisconsin USA.

Opara, C.C., 2009. Soil microaggregates stability under different land use types in southeastern Nigeria. Catena, 79: 103-112.

Razmi, Z., Sepaskhah, A.R., 2012. Effect of zeolite on saturated hydraulic conductivity and crack behavior of silty clay paddled soil. Archives of Agronomy and Soil Science, 58 (7): 805-816.
Rhoades, J.D., 1982a. Cation Exchange Capacity. Methods of Soil Analysis.Part 2. Chemical and Microbiological Properties. 2nd Edition. Agronomy No: 9, 149-157, 1159 p, Madison, Wisconsin USA.

Rhoades, J.D., 1982b. Soluble Salts, In: Page, A.L. (Ed.), Methods of Soil Analysis, Part 2, Chemical and Microbiological Properties, 2nd ed.: ASA, SSSA, Agronomy No: 9. Madison, Wisconsin, pp. 167-179.

Sepaskhah A.R., Barzegar, M. 2010. Yield, water and nitrogen-use response of rice to zeolite and nitrogen fertilization in a semi-arid environment. Agricultural Water Management, 98: 38-44.

Shirani, H., Hajabbasi, M.A., Afyuni, M., Hemmat, A., 2002. Effects of farmyard manure and tillage systems on soil physical properties and corn yield in central Iran. Soil and Tillage Research, 68: 101-108.

Sojka, R.E., Lentz, R.D., 1997. Reducing furrow irrigation erosion with polyacrylamide (PAM). Journal of Production Agriculture, 10 (1): 4752.

Susana, S., Roxana, V., Mignon, S., Vlad, S., Valentina, S., Bogdan, M., 2015. Using assessment of zeolite amendments in agriculture. ProEnvironment, 8: 85-88.

Torma, S., Vilcek, J., Adamisin, P., Huttmanova, E., Hronec, O., 2014, Influence of natural zeolite on nitrogen dynamics in soil Turk Journal Agric For., 38: 739-744.

Wallace, A., Terry, R.E., 1998. Handbook of Soil Conditioners: Substances that Enhance the Physical Properties of Soil. Marcel Dekker, New York.

Wang, S., Peng, Y., 2010. Natural zeolites as effective adsorbents in water and wastewater treatment. Chemical Engineering Journal, 156: 11-24.

Wehtje, G.R., Shaw, J.N., Walker, R.H., Williams, W., 2003. Bermudagrass growth in soil supplemented with inorganic amendments. Horticultural Science, 38 (4): 613-617.

Whalen, J.K., Chang, C., 2002. Macroaggregate characteristics in cultivated soils after 25 annual manure applications. Soil Science Society of America Journal, 66: 1637-1647.

Xiubin, H., Zhanbin, H., 2001. Zeolite application for enhancing water infiltration and retention in loess soil. Resources Conservation and Recycling, 34 (1): 45-52.

Zhao, B.Z., Xu, F.A., 1995. Improvement of soil physical properties with soil conditioners. Pedosphere, 5 (4): 363-370. 